\title{
Comparison of Demography of Sympatric Populations of Microtus ochrogaster and Synaptomys cooperi
}

\author{
Larry E. BEASLEY \& Lowell L. GETZ
}

\begin{abstract}
Beasley, L. E. \& Getz, L. L. 1986: Comparisons of demography of sympatric populations of Microtus ochrogaster and Synaptomys cooperi. Acta theriol. 31, 28: 385-400 [With 4 Tables \& 6 Figs.]

Comparisons wede made of demographic traits of Microtus ochrogaster and Synaptomys cooperi cohabiting a fescue habitat in southern Illinois, 1972-1974. Both species underwent a complete population cycle during the course of the study. Population density changes of the two species were in general synchrony; the increase phase of the $S$. cooperi population was more gradual and the peak density lower than were those of the $M$. ochrogaster population. The breeding season of both species was twice as long during the increase phase as during the decline phase. Monthly adult survival rates of both species were similar throughout the population cycle. There was no difference in survival of cohorts of either species recruited into the population at different seasons. There was progressively lower survival of cohorts of both species recruited into the population during the increase, peak and decline phase of the population cycle, respectively. Juvenile survival of both species was lowest during the low phase of the population cycle, high during the increase and peak phases and decreasing during the decline phase. Presence of wounds and scars in both species was positively correlated with population density. Because of the similarity in demographic traits of the two species during the population cycle, and because $M$. ochrogaster is known to display multiannual cycles, $S$. cooperi is also assumed to be a cyclic species.
\end{abstract}

[Dept. Ecol., Ethol. and Evolution, Univ. Illinois, Urbana, Illinois 61801]

\section{INTRODUCTION}

Owing to the erratic occurrence of the southern bog lemming $S y$ naptomys cooperi, (Stegman, 1930; Howell, 1927; Burt, 1948; Getz, 1961) few demographic studies are available for this species. Information relating to possibility of multiannual cycles is particularly scarce. Gaines, et al. (1977) concluded that two of the three populations of $S$. cooperi they studied in eastern Kansas displayed multiannual population cycles; the third displayed annual fluctuations in population density. However, their data for 1970-1973 suggest only low, increase and "peak" phases for the former two populations; a distinct decline phase is not obvious for either population. In a subsequent paper dealing with dispersal from 
S. cooperi populations, Gaines et al. (1979) present graphs of population densities of the two "multiannual" populations from 1974-6. The authors do not provide demographic data or discuss presence of annual or multiannual population fluctuations in this latter paper. Inspection of the data for the entire period of January 1970-January 1976 indicates one of the populations (Grid B) displayed peak densities in December $1971(37 / \mathrm{ha})$ and February 1975 (58/ha). Population density of the other population (Grid D) was high in January 1973 (43/ha), and January! 1975 (34/ha). Thus, the longer term data suggest two of the three populations of S. cooperi in eastern Kansas to display multiannual population fluctuations.

In the midwest the normal habitat of $S$. cooperi differs from that of a presumed "cyclic" species, Microtus ochrogaster (low, moist, small, isolated grassy swales and higher, drier, larger, contiguous grasslands, respectively; Getz, 1961; Hoffmeister \& Mohr, 1972; Burt, 1948). Linzey (1984) found interspecific competition to prevent Synaptomys and Microtus from occurring in the same site; however, the two genera have been found to occur sympatrically elsewhere (Getz, 1961; Gaines, et al., 1977).

Although the prairie vole, Microtus ochrogaster, was sympatric with the Kansas S. cooperi populations, Gaines et al. $(1977,1979)$ did not compare demographic attributes of the two species. Since $M$. ochrogaster has been shown to display multiannual cycles (Krebs \& Myers, 1974; Getz et al., 1979), comparisons of demographic attributes of the two species might provide evidence for multiannual or annual cycles within S. cooperi populations.

The present paper compares demographic data from a $S$. cooperi population with that from a sympatric population of $M$. ochrogaster in southern Illinois. Both species underwent a complete "population cycle" during the course of the study.

\section{DESCRIPTION OF STUDY AREA}

The study was conducted in the University of Illinois Dixon Springs Agricultural Center in Pope County in southern Illinois (38.4N 88.3W). A $100 \times 100 \mathrm{~m}$ live-trap area was centered in a 16 ha grass and legume field bordered by grazed pasture on the north and south and by abandoned fields undergoing succession on the east and west; the grazed pasture and abandoned fields provided unsuitable microtine habitat.

A grass and legume mixture had been established on the study area three years prior to the initiation of the study in January 1972. The field had been grazed by cattle until September 1971, at which time it was released from grazing. The area was dominated by fescue (Festuca sp.) and orchard grass (Dactylis glomerata) during the first year of the 
study. By the third year the orchard grass was nearly replaced by fescue; several species of forbs (alfalfa, Medicago sativa; clover, Trifolium spp.; vetch, Vicia sp.; plantain, Plantago rugelii) had also become common by this time. In July 1973 the area was mowed approximately $30 \mathrm{~cm}$ above the ground to control thistle (Cirsium vulgare); the detritus was left on the field.

During the first three winter months of the study the vegetation was patchy; only $60 \%$ of the ground was covered $10 \mathrm{~cm}$ above the surface. With the onset of vegetation growth in the spring, complete vegetation cover was attained and remained so through the remainder of the study.

Precipitation in the region averages $117 \mathrm{~cm} /$ year, with the lowest amounts recorded during the months of June-Auguset. Prolonged dry spells during part of the growing season are not unusual. Summer rainfall for the area is normally insufficient to support a dense stand of green herbaceous vegetation. Soil moisture stored during the autumn, winter and spring supports vegetation growth through the dry months. Higher than normal precipitation was recorded during April, November and December 1972 and April, May, November and December 1973. The vegetation displayed signs of wilting during the summers of 1973 and 1974.

The frost free period ranges from 185 to 213 days in southern Illinois. Winters are normally mild; January is the coldest month of the year. Based on temperature-precipitation regimes of the region the following seasons were designated for comparative purposes: Winter, January-March; Spring, April-June; Summer, July-September; Autumn, October-December.

\section{METHODS}

Modified Fitch live-traps (Fitch, 1950) were positioned at a $10 \mathrm{~m}$ interval (121 stations) within the study area. The area was trapped monthly from January 1972 through December 1974. Two days prior to a trapping session the traps were prebaited with cracked corn. The traps were set, using cracked corn as bait, in the afternoon and checked at 0700 and 1500 hours the next three days. If at least $10 \%$ of the animals captured the third day had not been previously trapped that session, trapping was continued another day. When the night temperature was predicted to be less than $-7.0^{\circ} \mathrm{C}$ the traps were examined at 2100 hours. During parts of the summer the traps were checked at 1200 hours. The traps were provided with cotton during winter months and were covered with mulch during the summer. Trap mortality was $5.6 \%$ for the entire study. 
Individuals were marked by toe clipping; no more than two toes were removed from any foot. At each capture the following data were recorded: station number, animal number, weight, sex, reproductive condition (males: testes, scrotal or abdominal; females, pregnant or lactating), and presence of wounds and scars.

Population densities were calculated from the minimum number of animals known to be alive on the study area each trapping session. Marked individuals not caught during a given month, but captured in a subsequent month, were recorded as present each month from the first until the last capture. Population density of each species was adjusted to account for the effective sampling area of the outer traps. The boundary of the study area was increased by one half the home range diameter, as estimated from the average maximum distance between captures of individuals during a trapping session $(10$ and $16 \mathrm{~m}$, for effective areas of 1.10 and 1.16 ha for $S$. cooperi and M. ochrogaster, respeetively).

Similar monthly trapping was conducted in two 1 ha areas, one located $100 \mathrm{~m}$ to the west and the other $100 \mathrm{~m}$ to the east of the main study area, from April-September 1973. Only two S. cooperi and no $M$. ochrogaster marked in the main study area were captured in these two areas.

Trappability of the two species was calculated as the percentage of the voles known to be present on the area that were actually captured a given trapping session. The following average monthly trappability was observed: S. cooperi males $84(26-95 \%)$, females $80(29-100 \%)$; $M$. ochrogaster males $82(62-98 \%)$, females $88(33-96 \%)$. Individual male and female $S$. cooperi averaged 1.5 and 1.3 captures, respectively, per each trapping session; male and female $M$. ochrogaster averaged 2.1 and 2.0 captures, respectively.

\section{SPECIES PRESENT}

During the three year study $666 \mathrm{M}$. ochrogaster, $560 \mathrm{~S}$. cooperi, 52 Peromyscus maniculatus (deer mouse), 26 Mus musculus (house mouse), 18 Blarina brevicauda (short-tailed sshrew), and 8 Cryptotis parva (least shrew) were captured.

Mammalian predators recorded in the study area were the long-tailed weasel (Mustela frenata), raccoon (Procyon lotor), opossum (Didelphis marsupialis), gray fox (Urocyon cinereoargenteus), red fox (Vulpes vulpes), and domestic cat (Felis catus). Sparrow hawks (Falco sparverius), marsh hawks (Circus cyaneus), red-tailed hawks (Buteo jamaicensis), 
speckled king snakes (Lampropeltis getulus), and blue racers (Coluber constrictor) were also observed in the area.

\section{RESULTS}

\subsection{Population Density}

Both species appeared to exhibit one complete population "cycle" during the course of the study (Fig. 1). Populaiton densities of C. cooperi

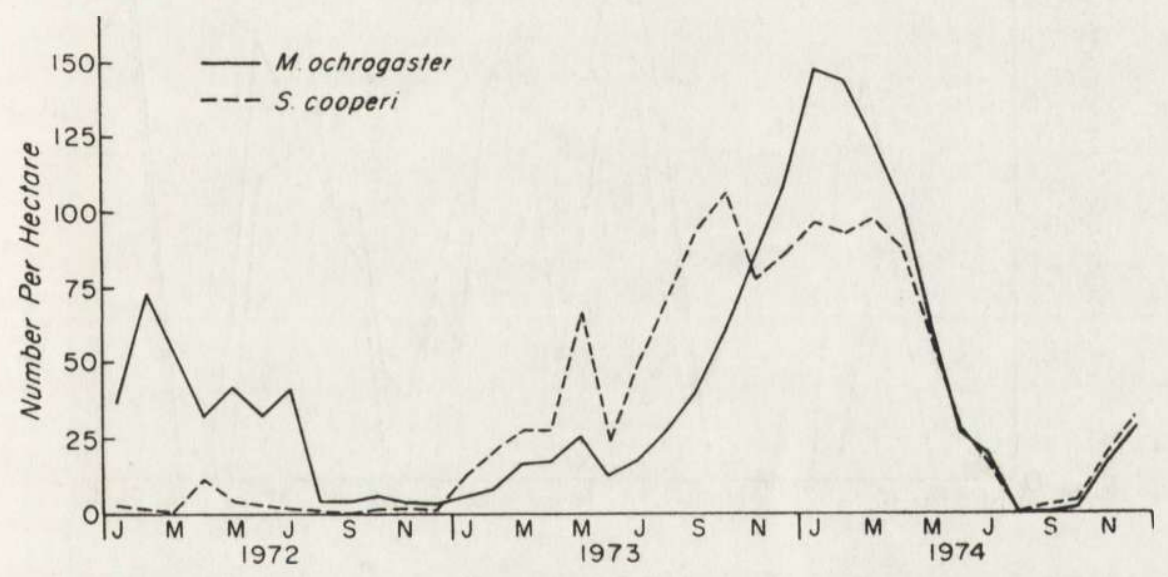

Fig. 1. Population densities of Microtus ochrogaster and Synaptomys cooperi.

remained low throughout 1972. An increase phase began in January 1973 and continued through the summer and autumn to a peak density of $106 / \mathrm{ha}$ in October. The population increased at a rate of $61.2 \%$ month from January through May. Following a brief decline in June, the population grew at a rate of $40.0 \% /$ month until the October peak. Population density remained relatively high until April 1974. This was followed by $45.2 \% /$ month decline from May to August 1974 , at which time no $S$. cooperi was captured on the area. The population was increasing again when trapping ended in December 1974.

Population density of $M$. ochrogaster was relatively high $(33-72 / \mathrm{ha})$ from January-April 1972; numbers then declined to a low of $4 / \mathrm{ha}$ in August 1972 and remained low throughout the autumn and winter of 1972-3. An increase phase began in March 1973 and continued to a peak of $147 / \mathrm{ha}$ in January 1974 . The population grew at a rate of $77.2 \%$ /month from March to May and at a rate of $48 \% /$ month from July 1973 through January 1974. The short peak phase was followed by a decline $(41.2 \% /$ month) through July 1974 . Population density was increasing again during November and December 1974. 
"Although the two populations were in general synchrony, the increase phase of the $S$. cooperi cycle began two months prior to and was more gradual than that of $M$. ochrogaster. The peak density of $S$. cooperi was lower than that of $M$. ochrogaster, 106 and $147 /$ ha, respectively; however, the peak phase of $S$. cooperi was longer than that of $M$. ochrogaster, 8 and 2 months, respectively.

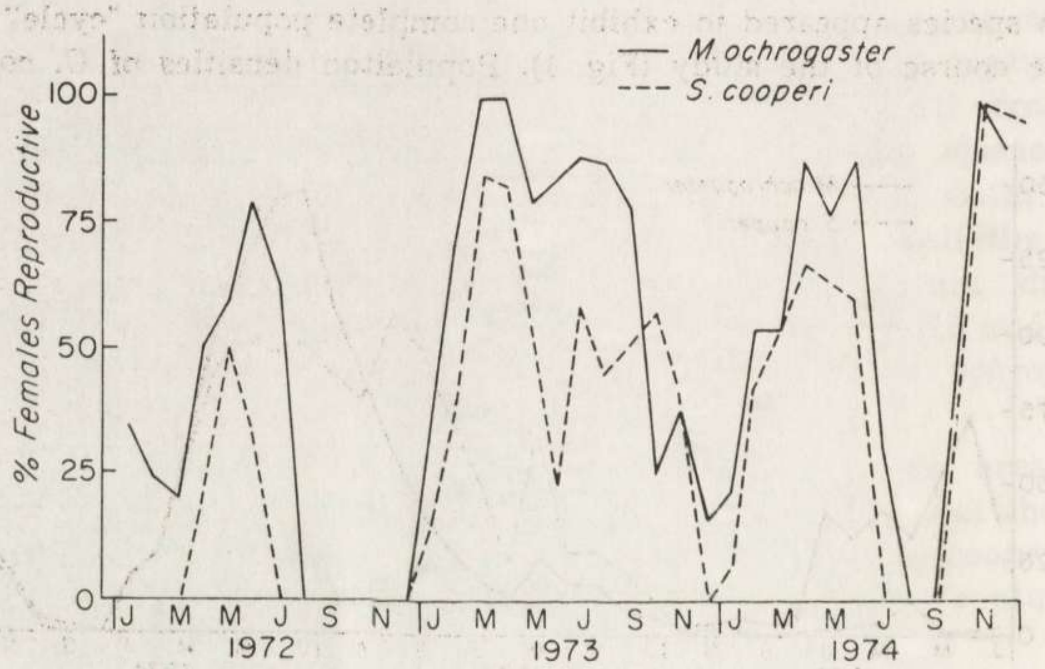

Fig. 2. Percent of female Microtus ochrogaster and Synaptomys conperi that were pregnant or lactating.

\subsection{Sex Ratio}

Of the $560 \mathrm{~S}$. cooperi captured during the study, 304 were males; the sex ratio deviated significantly from $1: 1 \quad\left(\xi^{2}=4.12, p<0.05\right)$. The overall sex ratio of $M$. ochrogaster was weighted towards females $(335: 311)$; the difference was significant at the 0.05 level $\left(\xi^{2}=2.90\right)$.

The sex ratio of $S$. cooperi was skewed towards females at the end of each period of increased breeding activity: October 1973, 41:70; June $1974,12: 20$. Females of $M$. ochrogaster also outnumbered males at the end of the 1974 breeding period (22:43), but the sex ratio was approximately equal at the end of the 1973 breeding period (31:28). During the nonbreeding seasons males of both species outnumbered females (59:32 and 76:66, S. cooperi and $M$. ochrogaster, respectively).

\subsection{Reproduction}

At least some females of both species were observed to be in reproductive condition (pregnant or lactating) throughout most of the year 
(Fig. 2). Those months during which no reproductive female was observed were periods of low population density when very few adult females were captured. We define the "breeding season" as those periods during which approximately $50 \%$ or more of the adult females were pregnant or lactating.

Table 1.

Proportion of the females reproductively active (pregnant or lactating) and phase of the population cycle.

\begin{tabular}{lcc}
\hline Phase of population cycle & N & Percent reproductive \\
\hline Increase & & \\
S. cooperi Jan.-Oct. '73 & 282 & 56.4 \\
M. ochrogaster Jun.-Dec. '73 & 171 & 40.9 \\
Peak & & $37.0^{*}$ \\
S. cooperi Nov. '73-April '74 & 284 & 46.7 \\
M. ochrogaster Jan.-Mar. '74 & 208 & 58.3 \\
Decline & 60 & $78.9 *$ \\
S. cooperi May-Jul. & 142 & \\
M. ochrogaster Apr.-Jul. & & \\
* Difference from other phases for that species significant at \\
0.001 level ( $\xi^{2}$, with Yates Correction; Zar, 1974).
\end{tabular}

Table 2

Proportion of the females reproductively active (pregnant or lactating) during given seasons. Sample sizes in parentheses.

Percent reproductive

S. cooperi M. ochrogaster

1973

\begin{tabular}{|c|c|c|}
\hline $\begin{array}{l}\text { Jan.-Mar. } \\
\text { Apr.-Jun, } \\
\text { Jul.-Sep. } \\
\text { Oct.-Dec. }\end{array}$ & $\begin{array}{l}71.0(31)^{\mathrm{i}} \\
53.1(64)^{\mathrm{i}} \\
50.4(113)^{\mathrm{i}} \\
41.0(166)^{\mathrm{p}}\end{array}$ & $\begin{array}{l}73.9(23) \\
62.5(32)^{\mathrm{i}} \\
83.3(48)^{\mathrm{i}} \\
25.6(117)^{\mathrm{i}}\end{array}$ \\
\hline 1974 & & $z$ \\
\hline $\begin{array}{l}\text { Jan.-Mar. } \\
\text { Apr.-Jun. } \\
\text { Jul. }\end{array}$ & $\begin{array}{c}34.3(140)^{\mathrm{p}} \\
41.2(107)^{\mathrm{d}} \\
0(5)^{\mathrm{d}}\end{array}$ & $\begin{array}{l}29.3(208)^{\mathrm{p}} \\
85.6(125)^{\mathrm{d}} \\
29.4(17)^{\mathrm{d}}\end{array}$ \\
\hline
\end{tabular}

i increase phase of population cycle; peak phase of population cycle; d decline phase of population cycle;

Reproduction in $M$. ochrogaster declined from January through March 1972; a four month breeding season (April-July) followed. There was a slightly lower period of reproductive activity in S. cooperi from April 
through June 1972. Reproduction of $M$. ochrogaster was high for eight months in 1973, February through September (Fig. 2). Onset of the 1973 breeding season occurred one month later (March) for S. cooperi, but continued through October. The 1974 breeding season of $M$. ochrogaster also began in February, but ended three months earlier (April) than it did in 1973. The $1974 \mathrm{~S}$. cooperi breeding season also lasted for five months, February through June. Breeding had increased to high levels again in both species during the autumn of 1974 .

During 1973, when the populations were increasing, both species displayed breeding seasons approximately twice as long as those in between season and phase of the population cycle in regard to differences in reproductive activity of females of either species during the increase, peak and decline phases of the population cycle was reduced reproduction during the peak phase of $S$. cooperi and increased reproduction during the decline phase of $M$. ochrogaster (Table 1). In general, reproduction remained at a relatively high level throughout the decline phase of both species.

The relationship between reproduction and phase of the population cycle appeared only partially influenced by seasonal differences in reproduction (Table 2). However, since only one and one-half years of reproduction data are available, we cannot analyze the relationship between season and phase of the population cycle in regard to differences in reproduction. We do not have data from the necessary repetition of phases and seasons to make such an analysis.

\subsection{Survival}

Persistence on the study area following first capture was used as an index of survival. We assumed an individual entered the population midway between the trapping session in which it was first captured and the preceding session, and left the population midway to the trapping session following its last capture.

Overall survival of male and female $S$. cooperi was 2.6 and 3.2 months, respectively; the difference was significant at the 0.05 level $(t=2.23$, $435 \mathrm{df}$ ). Average survival of male and female $M$. ochrogaster over the entire study did not differ significantly; 2.4 and 2.5 months, respectively. Female $S$. cooperi survived approximately 0.7 months longer than did female $M$. ochrogaster. Survival of male $S$. cooperi on the study area was only 0.2 months longer than that of male $M$. ochrogaster. When data for both sexes were combined, there was no significant difference in average survival of the two species over the entire study $(t=0.01$, $831 d f)$. 
There was no significant difference between 30 -day survival rates of males and females of either species (Figs. 3 and 4). Survival of the two species was approximately the same during the mid summer months as during the winter. Likewise, survival of both species declined slightly

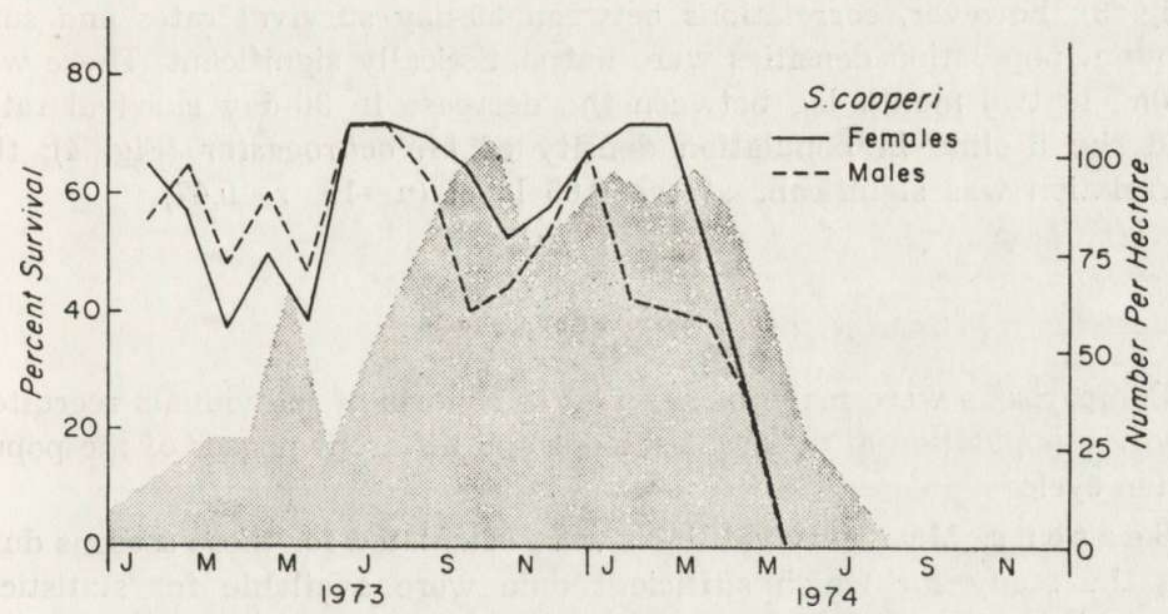

Fig. 3. Mean survival rate per month for Synaptomys cooperi. Data for all age classes combined. Shaded area represents population density.

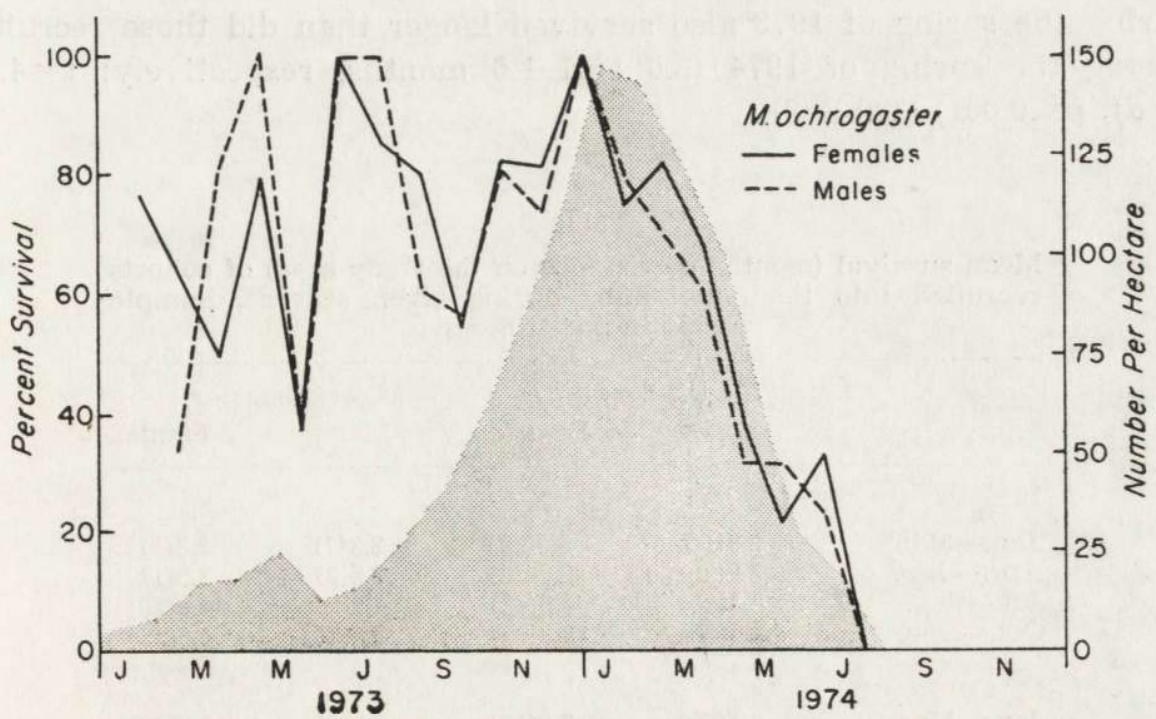

Fig. 4. Mean survival rate per month for Microtus ochrogaster. Data for all age classes combined. Shaded area represents population density. 
during September and October 1973. Survival declined precipitously during the decline phase of both populations in the spring of 1974 .

There was no correlation between increased survival and increases in population density of either species. Declines in survival of $S$. cooperi preceeded declines in population density by approximately three months (Fig. 3); however, correlations between 30-day survival rates and subsequent population densities were not statistically significant. There was a one to two month lag between the decrease in 30-day survival rates and the decline in population density of $M$. ochrogaster (Fig. 4); the correlation was significant at the 0.05 level $(n=19, r=0.47)$.

\subsection{Survival of Cohorts}

Comparisons were made of survival of cohorts of individuals recruited into the population at different seasons and different phases of the population cycie

S e a s on s. Mean survival times were calculated for those seasons during the study for which sufficient data were available for statistical comparisons (January 1973-June 1974; Table 1). Because different phases of the population cycles were involved, data for the winter and spring of 1973 and 1974 were treated separately. Survival of spring cohorts of male S.-cooperi averaged 3.6 and 1.5 months during 1973 and 1974 , respectively $(t=3.0,62 d f ; p<0.01)$. Female $S$. cooperi recruited during the spring of 1973 also survived longer than did those recruited among the spring of 1974 (3.6 and 1.6 months, respectively; $t=4.16$, $63 d f, p<0.001$ ) (Table 3 ).

Table 3

Mean survival (months persistence on the study area) of cohorts recruited into the populations during given seasons. Sample size in parentheses.

\begin{tabular}{lllll}
\hline & \multicolumn{2}{c}{$S$. cooperi } & \multicolumn{2}{c}{ M. ochrogaster } \\
& Males & Females & Males & Females \\
\hline 1973 & & & & \\
Jan.-Mar. & $5.7(14)$ & $3.5(20)$ & $2.3(7)$ & $3.3(11)$ \\
Apr.-Jun. & $3.6(26)$ & $3.6(33)$ & $2.8(9)$ & $3.5(11)$ \\
Jul-Sep. & $3.3(40)$ & $4.6(42)$ & $4.5(25)$ & $4.0(23)$ \\
Oct.-Dec. & $2.6(55)$ & $3.8(43)$ & $4.2(70)$ & $4.6(55)$ \\
1974 & & & & \\
Jan.-Mar. & $2.1(43)$ & $2.8(19)$ & $2.0(47)$ & $2.7(48)$ \\
Apr-Jun. & $1.5(33)$ & $1,6(32)$ & $1.2(33)$ & $1.2(48)$ \\
Average & $2.6(211)$ & $3.2(189)$ & $2.4(191)$ & $2.5(196)$ \\
\hline
\end{tabular}


Since there was no significant difference in survival of male and female $M$. ochrogaster, data for the two sexes were combined for seasonal analyses. Survival oi $M$. ochrogaster was significantly greated during the spring of 1973 than that recorded for the spring of 1974 (Table 1; $t=5.76,9 d f, p<0.001)$.

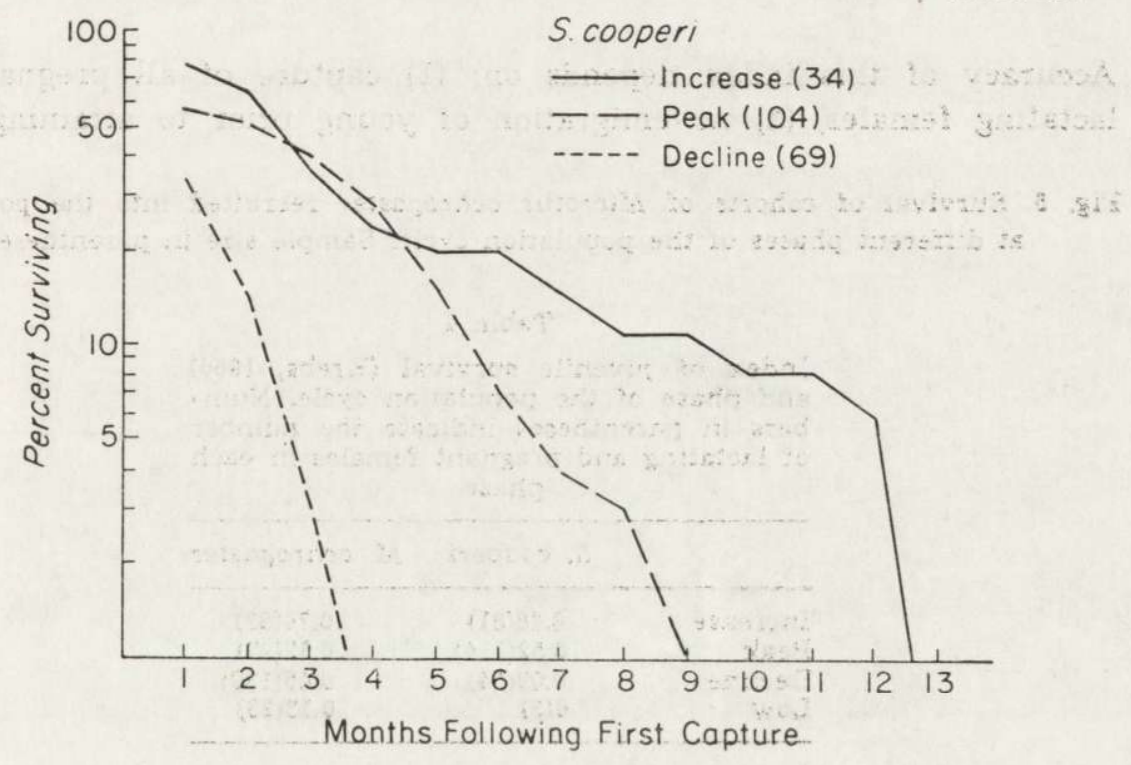

Fig. 5. Survival of cohorts of Synaptomys cooperi recruited into the population at different phases of the population cycle. Sample size in parentheses.

Although survival of winter-recruited cohorts of both species was somewhat greater during the winter of 1973 than during that of 1974, only that of male $S$. cooperi was statistically significant $(t=5.06,60 d f$, $p<0.001)$.

$\mathrm{Ph}$ a s e of population cycle. Cohorts (sexes combined for analysis) recruited into the population during the increase, peak and decline phases displayed progressively lower survival rates for both species (Figs. 5 and 6)

Only the increase phase was sufficiently long to test for homogeneity of survival within a given phase of the population cycle. There was no significant difference in survival of cohorts of either species recruited into the population at different times during this phase (spring, summer and autumn of 1973 for $S$.cooperi and summer and autumn 1973 for M. ochrogaster; Table 1). 


\subsection{Juvenile Survival}

The index of Krebs (1966) was used to estimate juvenile survival:

$\left.\begin{array}{c}\begin{array}{c}\text { index of } \\ \text { juvenile } \\ \text { survival }\end{array}\end{array}\right\}=\frac{\text { number of new voles less than } 30 \mathrm{~g} \text { in month } t}{\text { number of lactating and pregnant females in month } t-1}$

Accuracy of this index depends on: (1) capture of all pregnant and lactating females, (2) no emigration of young prior to attaining $30 \mathrm{~g}$,

Fig. 6. Survival of cohorts of Microtus ochrogaster recruited into the population at different phases of the population cycle. Sample size in parentheses.

Table 4

Index of juvenile survival (Krebs, 1966) and phase of the population cycle. Numbers in parentheses indicate the number of lactating and pregnant females in each phase.

\begin{tabular}{lll}
\hline & $S$. cooperi & M. ochrogaster \\
\hline Increase & $0.48(81)$ & $0.74(93)$ \\
Peak & $0.52(114)$ & $0.52(97)$ \\
Decline & $0.09(34)$ & $0.45(139)$ \\
Low & $0(2)$ & $0.13(23)$ \\
\hline
\end{tabular}

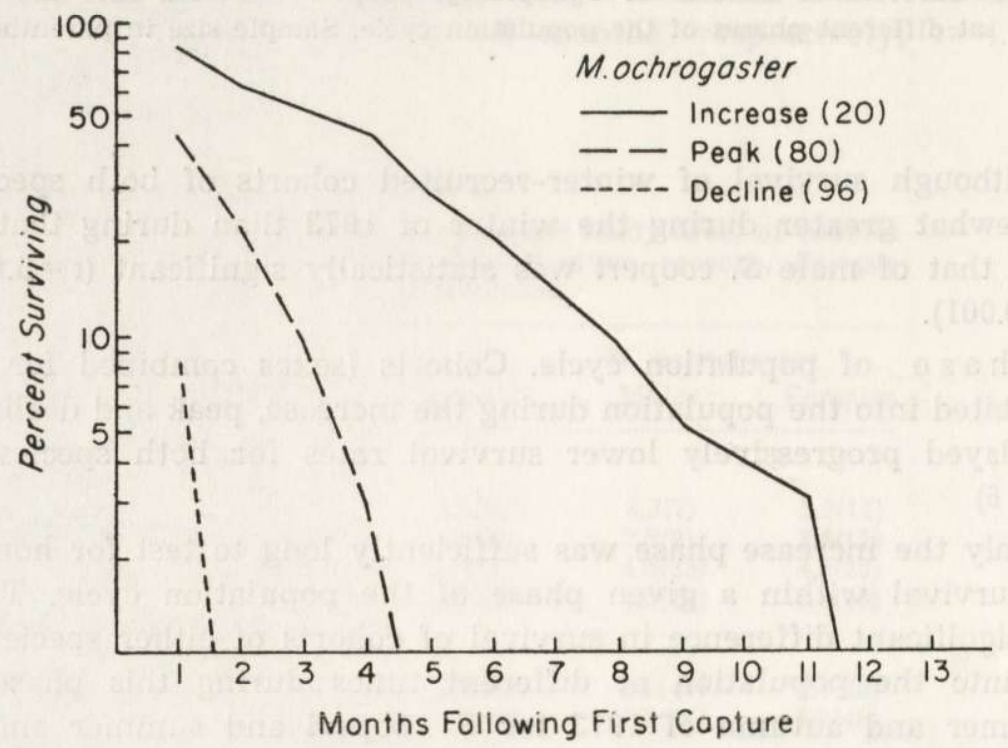


and (3) no change in litter size. As indicated above, most individuals were captured each session and there was reasonable evidence of only limited emigration from the study area. Krebs and Myers (1974) found that litter size of microtines does not change during the cycle. This index is therefore assumed to give a general approximation of juvenile survival during the population cycle.

Juvenile survival of both species followed the same pattern through the population cycle. Survival was low during the low phase, high during the increase, and peak phases, and decreasing during the decline phase (Table 3). Juvenile survival of $M$. ochrogaster was relatively high and greater than that of $S$. cooperi during the decline phase of the population cycle.

\subsection{Sears and Wounds}

Monthly comparisons indicated male $S$. cooperi displayed significantly more scars and wounds than did the females $(t=3.00,20 \mathrm{df}, 0.01>p>$ $>0.001)$. The difference in the proportion of males and females of $M$. ochrogaster with scars or wounds was not significant $(t=2.14,16 \mathrm{df})$ at the 0.01 level. Overall, male $S$. cooperi displayed a greater proportion of individuals with scars and wounds $(29.6 \%, N=304)$ than did male $M$. ochrogaster $(7.7 \%, N=311)$. There was no difference in the proportion of scars and wounds in female $S$. cooperi $(8.8 \%, N=256)$ and $M$. ochrogaster $(5.5 \%, N=355)$.

Presence of scars and wounds was positively correlated with population density in both male and female $S$. cooperi $(r=0.66,21 d f, p<$ $<0.001$ and $r=0.78,21 \mathrm{df}, p<0.001$, respectively). The proportion of $M$. ochrogaster (sexes combined) with scars or wounds was also positively correlated with population density $(r=0.70,21 d f, p<0.001)$.

The proportion of the $S$. cooperi population displaying scars and wounds was positively correlated with the number of reproductive individuals of the same sex (males, testes descended; females, lactating or pregnant) recorded in the population ( $r=0.91,20 \mathrm{df}, p<0.001$ and $r=$ $=0.78,20 \mathrm{df}, p<0.001$ for males and females, respectively). Male $S$. cooperi displayed significantly more scars and wounds than did females during the breeding season $(z=4.63, p<0.01$; Zar, 1974).

Presence of scars and wounds was also correlated with the number of reproductive male and female $M$. ochrogaster present in the population ( $r=0.81,21 d f, p<0.001$ and $r=0.86,21 d f, p<0.001$, respectively). There was no significant difference in the proportion of male and female $M$. ochrogaster displaying scars and wounds during the breeding season $(z=0.78)$. 


\subsection{Body Weights}

Mean body weights of male S. cooperi did not differ between the increase and peak phases of the population cycle ( 43.1 and $43.5 \mathrm{~g}$, respectively). Male $M$. ochrogaster tended to be only slightly (not significantly) heavier during the peak than during the increase phase (43.2 and $39.1 \mathrm{~g}$, respectively).

\section{DISCUSSION AND CONCLUSIONS}

Although the configuration, duration and amplitudes of fluctuation differed somewhat, the sympatric populations of Synaptomys cooperi and Microtus ochrogaster appeared to fluctuate in approximate synchrony. The general periods of high levels of reproduction were similar in the two species. The breeding season in both species persisted twice as long during the increase phase as during the decline phase of the population cycle. Both species displayed relatively high levels of reproduction during the decline phase. Reproduction did not drop to low levels for one and three months for $S$. cooperi and $M$. ochrogaster, respectively, following initiation of the decline phase. On general difference between the two species regarding reproduction was a smaller proportion of reproductive females in the $S$. cooperi population at all times. This lower reproductive activity may have been in part responsible for the lower peak densities achieved by the S. cooperi population.

There was no significant difference in average persistence of the two species on the study area. Adult survival preceded declines in population density in both species, three and one to two months for S. cooperi and $M$. ochrogaster, respectively.

Survival of given cohorts of both species varied with the phase of the cycle during which the individuals were recruited into the population. Cohorts entering the population in the spring of 1973 (increase phase) survived longer than did those recruited during the spring of 1974 (decline phase). Cohorts recruited during the winter of 1973 (increase phase) tended to survive longer than did those recruited during the winter of 1974 (peak phase). There was progressively lesser survival of individuals of both species entering the population during the increase, peak and decline phase, respectively. In addition, there was no difference in survival of individuals of either species entering the population at different times within the increase phase, the only phase for which there were sufficient data to test for homogeneity. Juvenile survival during different phases of the population cycle was also similar for the two species: lowest during the low phase, high during the increase and peak phases and decreasing during the decline phase. 
Presence of scars and wounds was used as an index of the level of aggressiveness within the population. Both species appeared to display a positive correlation between aggressiveness and population density. Likewise, the proportion of the population displaying scars and wounds was higher during the breeding than during the non-breeding seasons for both species. However, male $S$. cooperi had significantly more scars and wounds than did male and female $M$. ochrogaster or female $S$. cooperi. There was no difference in the proportion of female S. cooperi and $M$. ochrogaster with wounds and scars. These data suggest greater aggressiveness on the part of male $S$. cooperi; however, we have no way of knowing for certain who caused the injuries, i.e., other males competing with other males for females, or females resisting mating attempts.

Because of the general similarity in demographic traits we suggest that similar mechanisms are involved in population regulation of the two species.

\section{REFERENCES}

1. Burt W. H., 1948: The mammals of Michigan. Univ. Michigan Press, Ann Arbor

2. Fitch H. S., 1950: A new style live trap for small mammals. J. Mammal., 31: $364-365$.

3. Gaines M. S., Baker C. L. \& Vivas A. M., 1979: Demographic attributes of dispersing southern bog lemmings (Synaptomys cooperi) in eastern Kansas. Oecologia, 40: $91-101$.

4. Gaines M. S., Rose R. K. \& McClenaghan L. R. Jr., 1977: The demography of Synaptomys cooperi populations in eastern Kansas. Can. J. Zool., 55: 1584$-1594$.

5. Getz L. L., 1961: Factors influencing the local distribution of Microtus and Synaptomys. Ecology, 42: 110-119.

6. Getz L. L., Verner L., Cole F. R., Hofmann J. E. \& Avalos D. E., 1979: Comparison of population demography of Microtus ochrogaster and $M$. pennsylvanicus. Acta theriol., 24: 319-349.

7. Hoffmeister D. F. \& Mohr C. O., 1972: Fieldbook of Illinois mammals. Dover Publ. Inc. N.Y.

8. Howell A. B., 1927: Revision of the American lemming mice (genus Synaptomys). No. Amer. Fauna No. 50.

9. Krebs C. J., 1966: Demographic changes in fluctuating populations of Microtus californicus. Ecol. Monogr., 36: 239-273.

10. Krebs C. J., Keller B. L. \& Tamarin R. H., 1969: Microtus population biology: demographic changes in fluctuating populations of $M$. ochrogaster and $M$. pennsylvanicus in southern Indiana. Ecology, 50: 587-607.

11. Krebs C. J. \& Myers J. H., 1974: Population cycles in small mammals. Adv. Ecol. Res., 8: 267-399.

12. Linzey A. V., 1984: Patterns of coexistence in Synaptomys cooperi and Microtus pennsylvanicus. Ecology, 65: 382-393. 
13. Stegman L. C., 1930: Notes of Synaptomys cooperi cooperi in Washtenaw County, Michigan. J. Mammal., 11: 461-466.

14. Zar J. H., 1974: Biostatistical analysis. Prentice-Hall, Englewood Cliffs, N.J. Accepted, July 12, 1986.

\author{
Larry E. BEASLEY i Lowell L. GETZ \\ POROWNANIE DEMOGRAFII SYMPATRYCZNYCH POPULACJI MICROTUS \\ OCHROGASTER I SYNAPTOMYS COOPERI
}

\title{
Streszczenie
}

Porównano charakterystyki demograficzne populacji Microtus ochrogaster i Synaptomys cooperi żyjących $\mathrm{w}$ trawiastych ekosystemach na południu stanu Illinois w latach 1972-74. U obu gatunków zarejestrowano pelny cykl populacyjny w okresie badań. Zmiany zagęszczenia populacji dwu gatunków były zsynchronizowane, przy czym faza wzrostu liczebności $S$. cooperi była mniej gwałtowna a szczyt zagęszczenia niższy, niż w populacji $M$. ochrogaster. Sezon rozrodczy obu gatunków był dwukrotnie dłuższy $w$ fazie wzrostu $w$ porównaniu $\mathrm{z}$ fazą spadku liczebności. Przeżywalność dorosłych obu gatunków była podobna w ciągu całego cyklu. Nie znaleziono również u zadnego $\mathrm{z}$ gatunków różnic w przeżywalności kohort wchodzących do populacji w różnych porach sezonu rozrodczego. Przeżywalność kohort była najwyższa w fazie wzrostu, niższa w szczycie a najniższa w fazie spadku liczebności populacji. Przeżywalność młodych obu gatunków była najsłabsza w okresach niskiej liczebności, wysoka w czasie wzrostu i szczytu, a następnie zmniejszała się $\mathrm{w}$ fazie spadku liczebności. Liczba ran i skaleczeń osobników obu gatunków była dodatnio skorelowana z zagęszczenim populacji. W pracy wysunięto tezę, że $S$. cooperi jest również gatunkiem podlegającym cyklom populacyjnym, ponieważ jego charakterystyka demograficzna jest podobna do $M$. ochrogaster, który wykazuje wieloletnie cykle liczebności. 